\title{
Erratum to: DNA Barcoding for Diagnosis and Monitoring of Fungal Plant Pathogens
}

\author{
Prem Lal Kashyap, Pallavi Rai, Sudheer Kumar,
}

Hillol Chakdar, and Alok K. Srivastava

\section{Erratum to:}

B.P. Singh, V.K. Gupta (eds.), Molecular Markers in Mycology, Fungal Biology, DOI 10.1007/978-3-319-34106-4_5

In the original version of Chapter 5, few of the illustrations had permission issues. In the current version, Chapter 5 has been replaced with a new chapter with original figure.

The updated online version of the original chapters can be found under DOI 10.1007/978-3-319-34106-4_5 